\section{Cosmopolitan underwater fauna}

SIR-In their interesting letter published in Scientific Correspondence, Smith et al. ${ }^{2}$ reported their discovery of a chemosynthetic community on a whale carcass, and suggested that the whale's skeleton provided a source of sulphides to fuel their metabolism. But this speculative idea that this chemoautotrophic fauna is similar to hydrothermal vent faunae is not supported by other observations.

The Beggiatoa spp. mats described by Smith et al., for example, are ubiquitous on sulphide-rich environments such as intertidal mudflats, anoxic basins and fish farms $\mathrm{s}^{2-4}$, and are not restricted to vents and seeps. Further, of 219 published species of vent fauna, only 11 have been found in other habitats, including carcasses (V.T., unpublished data). The biogeographical patterns of true vent fauna are more likely to be related to seafloor spreading than by a fortuitous mechanism such as via carcasses of large animals.

In any event, the species described by Smith et al. are not all found in vents. The described molluscs exploit sulphide availability and are found in many such habitats. A few, like $C$. pacifica, may have the adaptations to enter vents and seeps. The truly endemic vent animals are not found on this carcass. But we do not believe that a few shared features between vent and whale carcass habitats provide evidence for an important dispersal mechanism.

Department of Biology,

VERENA TUNNICLIFFE

University of Victoria,

British Columbia, Canada V8W 2 Y2

Department of Oceanography,

University of Quebec.

Rimouski, Canada G5L $3 A 1$

1. Smith, C.R. et al. Nature 341, 27-28 (1989).

2. Jorgensen, B.B. Phil. Trans. R. Soc. B298, 543-561 (1982).

3. Juniper, S.K. \& Brinkhurst, R.O. Mar. Ecol. Prog. Ser. 33. 41-50 (1986)

4. Grant, J. \& Bathman, U.V. Science 236, 1472-1474 (1987)

\section{How secretion is inhibited}

SIR-It has been suggested ${ }^{1}$ that glucose inhibition of glucagon secretion is mediated by GABA activation of chloride channels in the pancreatic $\alpha_{2}$-cells, that the GABA is co-secreted with insulin from the pancreatic $\beta$-cells and that any cirumstances in which insulin secretion is stimulated will lead to suppression of glucagon release. This suggestion is an interesting possibility which, however, can hardly explain inhibition by glucose.

My scepticism originates from the physiology of glucose homeostasis. Whereas secretion of blood glucoselowering insulin begins above $4-5 \mathrm{mM}$ of the sugar, the release of blood glucoseraising glucagon is half-maximally inhibited by such concentrations ${ }^{2}$. The postulated glucose-induced co-secretion of GABA with insulin would consequently start in a concentration range where glucagon secretion is only marginally affected by the sugar.

An alternative explanation for glucose inhibition of glucagon release is a sugarinduced lowering of cytoplasmic $\mathrm{Ca}^{2+}$ caused by intracellular sequestration and outward transport ${ }^{3.4}$. Although the glucose dependence of this phenomenon has yet to be elucidated, it is noteworthy that a similar glucose-induced lowering of cytoplasmic $\mathrm{Ca}^{2+}$, which is a component in the action of the sugar on the pancreatic $\beta$-cell, is half-maximal at $6 \mathrm{mM}$ glucose $\mathrm{e}^{5}$.

A final comment concerns the citation of previous work. The original detection of GABA within the pancreatic islets was not made by Okada et al. ${ }^{6}$, although the authors probably believed this at the time. But the discovery was actually made four years earlier in two independent laboratories ${ }^{7,8}$.

Department of Medical Cell Biology,

University of Uppsala,

Biomedicum Box 571,

S-751 23 Uppsala, Sweden

1. Rorsman, P. et al. Nature 341, 233 (1989).

2. Gerich, J.E. et al. A. Rev. Physiol. 38,353 (1976).

. Johansson, H. et al. Biochem. Biophys. Res. Commun $147,309(1987)$.

. Johansson, H. et al. Cell Calcium 10, 205 (1989)

. Gylfe, E. J. biol. Chem. 263, 13750 (1988)

6. Okada, Y. et al. Science 194, 620 (1976).

Briel, G. et al. Acta physiol. Scand. 84, 247 (1972).

8. Panten, U. et al. FEBS Lett, 20,225 (1972)

\section{Diacylglycerol as messenger}

SIR-Smith et al. ${ }^{1}$ recently reported that the secretagogue glucose decreases the voltage threshold for activation of L-type $\mathrm{Ca}^{2+}$ channels in insulin-secreting cells. This finding nicely confirms, in normal rat pancreatic $\beta$-cells, results obtained with the carbohydrate secretagogue glyceraldehyde on the rat insulinoma cell line RINm5F (ref. 2). But it provides no information on the nature of the metabolic product supposed to stimulate the channels.

It is well established that $\mathrm{Ca}^{2+}$ channel function can be modulated by cyclic AMP-dependent phosphorylation ${ }^{3}$, but carbohydrate stimuli have little or no effect on cyclic AMP levels in insulinsecreting cells ${ }^{4}$. On the other hand, it is known that glucose and glyceraldehyde evoke rapid de novo synthesis of diacylglycerol in normal pancreatic $\beta$-cells ${ }^{5}$ and insulinoma cells ${ }^{6}$

Since the cell-permeable diacylglycerol analogue didecanoylglycerol has been shown to mimic the effect of carbohydrate secretagogues on gating of single L-type $\mathrm{Ca}^{2+}$ channels in insulinoma cells ${ }^{7}$, diacylglycerol may fulfil the required messenger role. Diacylglycerol could work by protein kinase C-mediated phosphorylation, or by an as yet unknown mechanism ${ }^{8}$.

O. H. PETERSEN

Physiological Laboratory,

University of Liverpool,

PO Box 147, Liverpool L69 3BX, UK

C. B. WOLLHEIM

Institut de Biochimie Clinique,

Centre Medical Universitaire,

Universite de Geneve,

1211 Geneve 4, Switzerland

1. Smith, P.A., Rorsman, P. \& Ashcroft, F.M. Nature 342 550-553 (1989)

2. Velasco, J.M., Petersen, J.U.H. \& Petersen, O.H. FEBS Lett. 231, 366-370 (1988)

3. Reuter, H. News physiol. Sci. 2, 168-171 (1987)

4. Prentki, M. \& Matschinsky, F.M. Physiol, Rev. 67, 1185$1248(1987)$

5. Peter-Riesch, B., Fathi, M., Schlege!, W. \& Woliheim, C.B. J. clin. Invest. 81, 1154-1161 (1988).

6. Wollheim, C.B. et al. EMBO J. 7, 2443-2449 (1988).

7. Velasco, J.M. \& Petersen, O.H. Q. J. exp. Physiol. 74, 367-370 (1989).

8. Kolesnick, R.N. J. biol. Chem. 262, 16759-16762 (1987).

\section{Copper-bottomed earwax}

SIR-The unexplained liking of several cats for human ear wax (Nature 343, 220; 1990 ) is a reminder that pica, a desire for unusual food, can sometimes be traced to dietary deficiency, such as a lack of iron ${ }^{1}$. Cerumen (ear wax) has a high copper content ${ }^{2}$, which may relate to its bactericidal and mycocidal properties ${ }^{3}$. Copper occurs in most tissues of the animal body, and minute amounts are necessary for the incorporation of iron into haemoglobin ${ }^{4}$. In the cytochrome system, the function of copper is similar to that of iron. Copper requirements vary among species, and are influenced by the intake of other mineral elements such as iron and molybdenum $^{5}$. If there is a copper deficiency, anaemia is a common sequel ${ }^{4}$.

It may be that some domestic animals experience a copper-deficient diet, leading them to seek supplementary sources of this mineral.

PATRICKM.P. O'CONNOR

Department of Radiology,

Albany Medical Center Hospital,

Albany, New York 12208, USA

1. Reynolds, R.D. et al. Ann. int. Med. 69, 435-440 (1968) 2. Yassin, A., Mostafa, M.A. \& Moawad, M.K. J. laryngol. Otol. 80, 933-937 (1966).

Megarry, S. et at. f. laryngol. Otol, 102, 671-672 (1988)

4. Jones, C.J. \& Hunt, R.D. in Veterinary Pathology 1066 1068 (Lea \& Febiger, Philadelphia, 1983).

5. Hays, V.W.. Swenson, M.J. in Dukes' Physiology of Domestic Animals (ed Swenson, M.J.) 395-412 (Comstock, Ithaca, 1977). 